International Research Journal of Public and Environmental Health Vol.9 (1),pp. 1-9, February 2022

Available online at https://www.journalissues.org/IRJPEH/

https://doi.org/10.15739/irjpeh.22.001

Copyright (C) 2022 Author(s) retain the copyright of this article

ISSN 2360-8803

Check for updates

Review

\title{
Nitrate removal from drinking water using different reactor/membrane types: A comprehensive review
}

\author{
Wael S. Al-Rashed ${ }^{1}$ \\ and \\ Abderrahim Lakhouit ${ }^{1 *}$ \\ ${ }^{1}$ Department of Civil Engineering, \\ Faculty of Engineering, \\ University of Tabuk, P.O. Box 741 \\ Tabuk 71491, Kingdom of Saudi \\ Arabia. \\ *Corresponding Author \\ Email: a.lakhouit@ut.edu.sa
}

\begin{abstract}
Nitrate is considered one of the key contaminants in drinking water sources, particularly groundwater. This could be a result of excessive human activities. Numerous studies have been successfully developed and are still developing eco-friendly and cost-effective treatment techniques for highly efficient nitrate removal from drinking water. Although most of the nitrate removal techniques are physically and chemically based, for example, ion exchange and reverse osmosis, biological treatment is an equally potent approach applied in full scale through autotrophic and heterotrophic denitrification. However, many studies are trying to reduce some of the disadvantages of the biological treatment, such as the need for further treatment for microbial or organic carbon removal. This paper addresses some of the conventional nitrate removal approaches and reviews the biological denitrification processes, highlighting the advantages and disadvantages of the following methods: (i) conventional nitrate removal techniques, (ii) biological denitrification via bioreactor membrane techniques, (iii) membrane bioreactor (MBR), (iv) membrane biofilmreactor (MBfR), (v) ion exchange membrane bioreactor (IEMBR), and (vi) biofilm-electrode reactor (BER).
\end{abstract}

Keywords: Drinking water, nitrate removal, biological denitrification, bioreactor

\section{INTRODUCTION}

Environmental organizations around the world are concerned about the quality of drinking water, particularly the several eminent containments in groundwater. Furthermore, nitrate is regarded as one of the key contaminants in groundwater. Nitrate is a naturally occurring anion in the environment as a product of nitrogen gas oxidation, a component of the nitrogen cycle required by living organisms for the production of various organic compounds. Furthermore, nitrate can be formed in drinking water distribution systems as a result of the nitrification process, where the already present ammonia is oxidized to nitrite, which is then oxidized to nitrate. Moreover, various elements influence the nitrification process, including $\mathrm{pH}$, temperature, and the concentration of ammonia, as well as physical and hydraulic factors such as water retention time in polluted pipes (Kinyage et al.,2019; US.EPA, 2002). Drinking nitrate-contaminated water has been associated with significant disorders such as methaemoglobinemia (blue baby syndrome). The rationale for this designation is that infants (less than six months old) are more susceptible to such diseases as compared to other age groups, in addition to other cancerous diseases (Temkin et al., 2019; Health Canada, 2013).

The maximum permitted concentration of nitrate in drinking water is $50 \mathrm{mg} / \mathrm{L}$ (WHO, 2011). Furthermore, the Canadian drinking water regulation for nitrate is $45 \mathrm{mg} / \mathrm{L}$ as nitrate, which is equivalent to $10 \mathrm{mg} / \mathrm{L}$ as $\left(\mathrm{NO}_{3}^{--}-\mathrm{N}\right)$ 
(Health Canada, 2013). The rapid increase in human activities (agriculture-fertilizers) has contributed to a rise in nitrate concentrations in groundwater. Additionally, factors such as soil characteristics, aging of water in aquifers, and geochemistry have also influenced nitrate concentrations in groundwater (Dubrovsky and Hamilton, 2010). Direct human exposure to nitrate through water and food, e.g., eating vegetables polluted with high levels of nitrate, has raised the interest in regulating drinking water sources. This provided the impetus for researchers to develop effective and dependable nitrate removal techniques. Accordingly, numerous such strategies have been developed for reducing the carbon footprint as well as the overall treatment and operating costs. Moreover, water treatment via bioreactor membranes has been extensively researched with different configurations. This paper aims to review different nitrate removal bioreactor membranes with different configurations and compare their denitrification efficiencies, overall performance, and other aspects.

\section{Conventional nitrate removal techniques (chemical and physical)}

The chemical and physical properties of nitrate made it challenging to treat using conventional water treatment methods, such as coagulation, sedimentation, and filtration. As a result, advanced treatment techniques such as ion exchange and reverse osmosis (RO) were developed for nitrate removal (Guter, 2021; McAdam and Judd, 2006; Fonseca, 2000). The effectiveness of the ion exchange process for nitrate removal made this type of treatment one of the most prevalent chemical treatments to be used in drinking water plants. Furthermore, the ion exchange operation involves treating nitrate contaminated water by replacing it with a counter anion $\left(\mathrm{Cl}^{-}\right.$or $\left.\mathrm{HCO}_{3}^{-}\right)$in a bed with high levels of a strong base; the bed will be saturated, necessitating a further regeneration or replacement process. Additionally, the waste concentrate from ion exchange is highly polluted with excessive salt levels. Thus, appropriate disposal measures are needed for their disposal. These two issues are regarded as significant drawbacks of the ion exchange treatment (McAdam and Judd, 2008).

Physical treatments such as RO apply high pressure through a dense membrane that only allows water molecules to pass through, retaining all the dissolved salts and ions in the raw water, including nitrate (Missimer et al., 2013). However, the performance of RO membranes is limited by the membrane fouling issue, which can be resolved through the pre-treatment of raw water (Fangang et al., 2008). Furthermore, it has been observed that the operational and maintenance costs of RO are significantly higher than those of the ion exchange process, making it less feasible and, therefore, less used in such treatment objectives.

Electro-dialysis is another treatment technology that uses a combination of electrical and chemical processes to remove different ions by forcing polluted water to pass through a membrane stacked with alternative anions and cations, driven by direct current (DC) force. Subsequently, the ion exchange membrane then removes the nitrate and washes it out in the waste product. Concerning the technique's shortcomings, it is apparent that the system's complex operational features, in addition to the highly contaminated waste that necessitates additional treatment, could impede performance in full-scale applications. Furthermore, the required $\mathrm{pH}$ adjustment could be viewed as an operational disadvantage (Kapoor and Viraraghaven, 1997; Health Canada, 2013).

\section{Biological Denitrification via Bioreactor Membrane Techniques}

Biological denitrification is an alternative nitrate removal technique, where nitrate acts as an electron acceptor in anoxic conditions, in the presence of microbial biomass (denitrifying bacteria). This process aims to reduce nitrate to nitrogen gas through a redox reaction. The following denitrification steps for nitrate reduction have been proposed by Knowles (1982):

$\mathrm{NO}_{3}^{-} \rightarrow \mathrm{NO}_{2}^{-} \rightarrow \mathrm{NO} \rightarrow \mathrm{N}_{2} \mathrm{O} \rightarrow \mathrm{N}_{2} \quad$ Eq. 1

Organic carbon sources such as methanol, ethanol, and acetate are used in heterotrophic denitrification. Inorganic carbon compounds, such as hydrogen or sulfate, on the other hand, are used in autotrophic denitrification. They also serve as electron donors for bioreduction (Xia et al., 2010). Although this treatment technology is primarily intended for wastewater treatment, numerous studies have been conducted to investigate nitrate removal from drinking water (Fabbricinoa et al., 2007; McAdam and Judd, 2006).

There are a variety of membrane/reactor configurations for nitrate bioreduction, including membrane bioreactors (MBR), membrane biofilm reactors (MBfR), and fixed or fluidized bed reactors (FBR). According to the researchers, biological denitrification requires additional post-treatment to remove residual organic matter that was detected at significantly high levels and is not suitable for drinking water uses. Adsorption, disinfection, and nanofiltration are among the proposed post-treatment methods (Meyer et al., 2010). In terms of full-scale applications, it was used in Europe to remove nitrate from drinking water many years ago (Dordelmann, 2009). Meyer et al. (2010), on the other hand, reported that full-scale biological denitrification is not as popular as chemical nitrate removal techniques (e.g., ion exchange) in North America as in Europe. A number of those biological treatment configurations have been demonstrated and reviewed in the following subsections. For drinking water, based on the process conditions, denitrification capacities based on reactor effluent and membrane effluent of up to $0.18 \mathrm{~kg} / \mathrm{m}^{3}$-day and 2.44 $\mathrm{kg} / \mathrm{m}^{2}$-day $\mathrm{NO}_{3}-\mathrm{N}$, respectively, have been obtained (Dordelmann, 2009). 


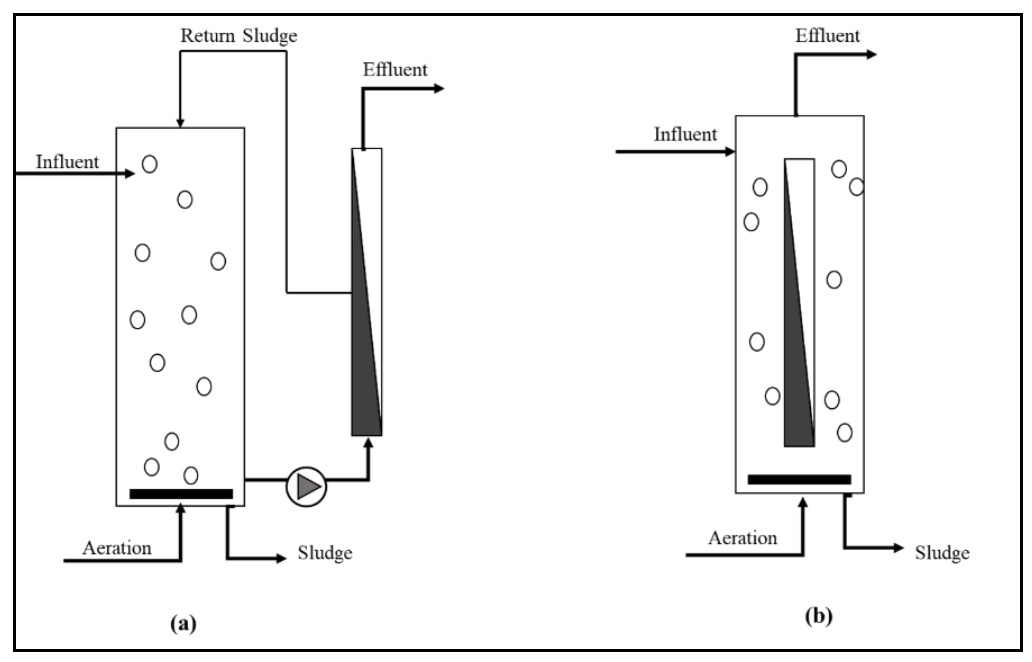

Figure 1: Schematic of basic MBRs configurations: (a) MBR with exterior MBR module and (b) MBR with submerged MBR module

Table 1. Denitrification rates and operating conditions in membrane bioreactors

\begin{tabular}{|c|c|c|c|c|c|c|c|c|}
\hline $\begin{array}{l}\text { Electron } \\
\text { Donor }\end{array}$ & $\begin{array}{c}\text { Reactor } \\
\text { Volume } \\
\text { (L) } \\
\end{array}$ & $\begin{array}{l}\text { HRT } \\
\text { (h) } \\
\end{array}$ & $\mathrm{C} / \mathrm{N}$ & $\begin{array}{c}\mathrm{NO}_{3}-\mathrm{N} \\
\text { Loading } \\
\text { Rate } \\
\text { (g/L. d) }\end{array}$ & $\begin{array}{c}\mathrm{NO}_{3}-\mathrm{N} \\
\text { denitrification } \\
\text { rate }\left(\mathrm{g} / \mathrm{m}^{2} . \mathrm{d}\right)\end{array}$ & $\begin{array}{c}\mathrm{NO}_{3}-\mathrm{N} \\
\text { Influent } \\
(\mathrm{mg} / \mathrm{L})\end{array}$ & $\begin{array}{c}\text { Removal } \\
\text { Efficiency } \\
(\%) \\
\end{array}$ & References \\
\hline $\mathrm{CH}_{3} \mathrm{OH}$ & 4.5 & 1.2 & & 4 & 3.6 & & 99 & $\begin{array}{c}\text { Ergas and Rheinheimer } \\
(2004)\end{array}$ \\
\hline $\mathrm{C}_{2} \mathrm{H}_{6} \mathrm{O}$ & 5 & 2.5 & $1.4-2.5$ & - & - & 10 & 99 & Ravnjak et al. (2013) \\
\hline $\mathrm{CH}_{3} \mathrm{OH}$ & 0.02 & $0.24-0.55$ & & 0.8 & 4 & 20 & 90 & $\begin{array}{c}\text { Mansell and Schroeder } \\
\text { (1999) }\end{array}$ \\
\hline $\mathrm{C}_{2} \mathrm{H}_{6} \mathrm{O}$ & 0.5 & $9-12$ & $1.9-4$ & 0.041 & 0.75 & 34 & - & Fuchs et al. (1997) \\
\hline $\mathrm{C}_{2} \mathrm{H}_{6} \mathrm{O}$ & 1.2 & 96 & - & - & 2.4 & - & 99 & Zhang et al. (2011) \\
\hline
\end{tabular}

\section{Membrane Bioreactor (MBR)}

The MBR technology has been thoroughly investigated in both laboratory and full pilot scale for wastewater treatment. Figure 1 depicts the MBR configuration. Due to microbial community utilization and additional carbon sources that require further treatment, MBR research associated with drinking water treatment is relatively less than that for wastewater treatment (Melin et al., 2006). There are numerous MBR configurations that are primarily designed with the main objective of wastewater treatment. The process, however, can be described as a biomass suspension in a reactor coupled to a separation-acting membrane. The nitrate-contaminated water flows through the membrane lumen and diffuses to a microbial culture (Buttiglieri et al., 2005). Furthermore, the membrane can function as a filter or a bioreactor. The extractive membrane bioreactor is one of the more interesting denitrifications MBR configurations. The nitrate-polluted water is extracted using a molecular diffusion process after it is passed through a tubular membrane. Additionally, in order to achieve the goal of nitrate removal, a microbial denitrifying culture is suspended in the media alongside an electron donor, such as ethanol or methanol. This type of treatment has some practical benefits when it comes to dealing with drinking water. According to Ergas and Rheinheimer (2004), the product of this treatment is completely isolated from the bulk microbial biomass where they have been used, and this is due to the advantage of using a microspores membrane, as well as inexpensive electron donors (methanol), to complete the redox reaction with nitrate (Martin and Nerenberg, 2012; McAdam and Judd, 2006). Regarding membrane configurations, both tubular and hollow-fiber membranes support the denitrification microbial culture in the membrane bioreactor (Wintgens et al., 2003; Martin and Nerenberg, 2012; Mao et al., 2020).

Ergas and Rheinheimer (2004) reported a high nitrate removal efficiency of $99 \%$ at a $\mathrm{NO}_{3}-\mathrm{N}$ with an influent concentration of $200 \mathrm{mg} / \mathrm{L}$ and that the average filtration rate was $6.2 \mathrm{~g} / \mathrm{m}^{2}$-d; other studies have reported different removal efficiencies, as presented in Table 1. Moreover, these authors focused on the impact of mass transfer in the reactor, stating that the membrane, feed, and permeate 
resistance are the key resistances that could affect the mass transfer in the reactor. Subsequently, the result showed that at low feed velocities, the mass transfer coefficient was affected in contrast to higher feed velocities. In Nuhoglu et al. (2002), the MBR system employed was able to offer $\mathrm{NO}_{3}$ $\mathrm{N}$ removals of up to $98.5 \%$.

The significance of organic carbon residual in effluent still concerns the current research for attaining drinking water with acceptable quality. Rabah and Dahab (2004) reported that biological denitrification resulted in high organic matter levels in treated water. As a result, it was necessary to monitor the effluent for residual organic carbon and come up with an alternative solution to this problem. Ergas and Rheinheimer (2004) completed the denitrifying process with methanol as a carbon source; however, they reported a high methanol level $(30 \mathrm{mg} / \mathrm{L})$ in the effluent, indicating the need for post-treatment for carbon removal. This problem has highlighted one of the disadvantages of using heterotrophs in biological drinking water treatment. Similarly, Ravnjak et al. (2013) investigated the removal of nitrates from groundwater in addition to the organic carbon removal used in the bioreduction process. The authors created an anoxic/oxic two-stage membrane bioreactor with ethanol as the sole carbon source and a carbon to nitrogen ratio of 1.4-2.5. Furthermore, the reported removal efficiency was $99 \%$, with no nitrite accumulation in the effluent, indicating an acceptable use of organic carbon, which speeds up the kinetics of nitrate reduction to nitrogen gas. Total organic carbon (TOC) was measured in both reactor compartments, on the other hand (anoxic and oxic). The results showed that the TOC conversion percentage reached $75 \%$ during the anoxic phase. Moreover, after the effluent was pumped into the oxic phase (in the presence of oxygen), the TOC level was reduced to nearly that of the influent, signifying the impact of oxygen in lowering the organic carbon. Furthermore, the density and structure of the biofilm may have an effect on the organic carbon loading (Fuchs et al., 1997; McAdam and Judd, 2006). Zhang et al. (2011) conducted a study on groundwater denitrification using ethanol as an organic carbon source; their findings were similar to those of previous studies where ethanol was used as a carbon source with a high nitrate removal efficiency. However, the authors only investigated the batch mode performance of the membrane bioreactor, and no continuous mode operation was reported, reducing the research's reliability and validity. More research is needed to explore the impact of fixed and suspended biomass in membrane bioreactors on the organic carbon residual in treated water. The issue of nitrite $\left(\mathrm{NO}_{2}^{-}\right)$formation and accumulation as a result of the slow kinetics of nitrate reduction, overdosing of organic carbon, and uncontrolled biomass highlights the need for additional research (McAdam and Judd, 2006). However, research is still being conducted to overcome the aforementioned drawbacks of nitrate removal using various membrane bioreactors. Furthermore, the need for additional carbon sources may necessitate additional treatment to remove residual organic carbon and microbial contamination caused by biomass utilization (Ravnjak et al., 2013; Fuchs et al., 1997; Buttiglieri et al., 2005).

\section{Membrane Biofilm-Reactor (MBfR)}

The concept of utilizing gaseous substrates for water or wastewater treatment is not a novel idea. Aeration, for example, is a key concept in wastewater treatment, where continuous air bubbling is required for the complete oxidation of organic matter. In addition, methane or hydrogen are used as electron donors to remove a variety of organic and inorganic pollutants from raw water (Rezania et al., 2007). However, the drawbacks of such an approach must not be neglected, such as the low solubility of certain gases, which impedes the treatment process and forces operators to search for expensive solutions to this problem (Rittmann and Nerenberg, 2004). Therefore, the idea of using membranes to control gas diffusion to polluted solutions or biomass became more feasible. Rittmann was the first to investigate and name the membrane biofilm reactor MBfR technology (2006). Since then, the same concept has evolved and been extensively researched in both drinking water and wastewater treatment (Lee and Rittmann, 2002; Buttiglieri et al., 2005; Modin et al., 2008; Xia et al., 2010; Nerenberg 2012). The fundamental principle behind this technology is the use of a bubble-less diffusion of a pressurized gaseous electron donor, such as hydrogen, methane, air, and oxygen, to a cultured biofilm attached to the exterior of a hollow fiber membrane. At the same time, oxidized contaminants such as nitrate $\left(\mathrm{NO}_{3}{ }^{-}\right)$are introduced into the bulk liquid surrounding the hollow fiber membrane module, acting as electron acceptors (Martin and Nerenberg 2012; Xia et al., 2010; Buttiglieri et al., 2005). One of the main differences between MBfR and MBR is the MBR's ability to isolate suspended active biomass from treated water. This is one of the barriers to the use of MBfRs in drinking water treatment. There are also some differences, such as the gas transfer behavior to the liquid phase via the biofilm. In other words, the concept of counter-diffusional biofilm is a unique feature of the MBfRs, in contrast to the conventional biofilm diffusion behavior, as shown in Figure 2 (Martin and Nerenberg, 2012).

Xia et al. (2010) investigated denitrification in groundwater in MBfR using hydrogen gas as an electron donor (gaseous substrate) and a nitrate-nitrogen concentration of $5 \mathrm{mg} / \mathrm{L}$ as an influent. Moreover, they discovered a significant denitrification rate $\left(384 \mathrm{~g} \mathrm{~N} / \mathrm{m}^{3}-\mathrm{d}\right)$. Furthermore, they reported a removal efficiency of $100 \%$ after 45 days, indicating an exceptional acclimation of the denitrifying bacteria on the shell of the hollow fiber membrane. However, they emphasize the role of increasing hydrogen pressure on the denitrification rate under the $\mathrm{NO}_{3}-\mathrm{N}$ loading of $0.34 \mathrm{~g} / \mathrm{m}^{2}-\mathrm{d}$. This is logical since the concentration of the electron donor increases, which could directly impact microbial activity. Subsequently, the denitrifying rate increases. However, the water quality analysis for residual organic carbon, in which they 


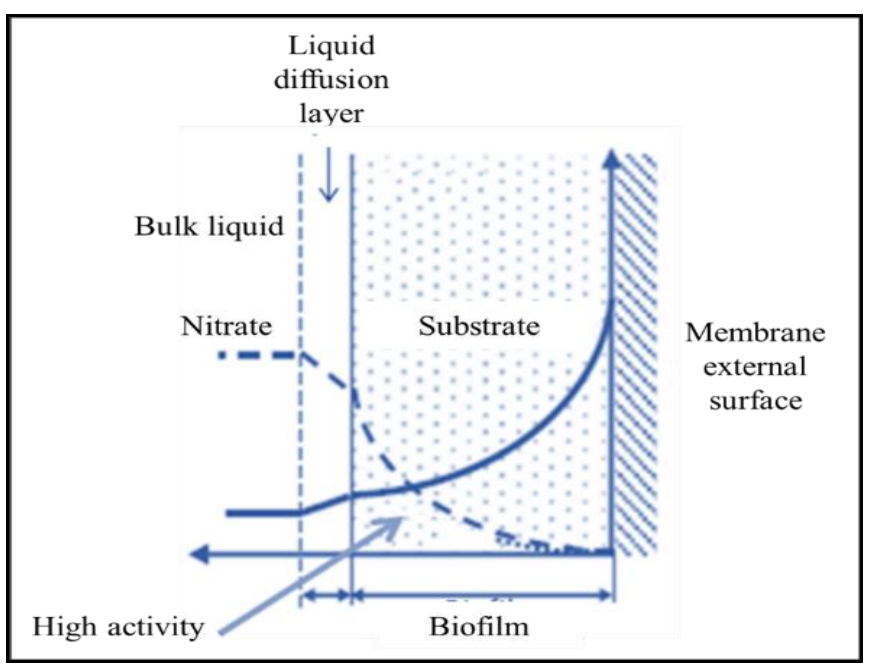

Figure 2: Counter-diffusional behavior in MBfR biofilm

Source: adapted from Martin and Nerenberg, 2012

examined the total organic carbon (TOC) and dissolved organic carbon (DOC), led the authors to conclude that additional post-treatment is required to overcome biological contamination. This microbial contamination is caused by biomass enrichment as well as a lack of a separation mechanism between the biomass and the treated water effluent. Chung et al. (2007) also investigated hydrogen gas as an electron donor in an MBfR system to remove nitrate and perchlorate. The purpose of the study was to look into the performance of the MBfR in reducing nitrate from a synthetic high salt solution $(\sim 15 \%)$, simulating the ion exchange brine. Moreover, the importance of this study is to observe the MBfR performance in such high nitrate concentrations. The result showed that the increase in hydrogen gas pressure had a direct impact on nitrate reduction kinetics, which supports Xia et al.'s (2010) observations. The pH value, salinity, dissolved oxygen, HRT (hydraulic retention time), and carbon source have been identified as the main operational conditions, affecting MBfR performance (Yin et al., 2018). The investigation of Aydin et al. (2016) showed that nitrate removal (99\%) took place successfully under the conditions of $5 \mathrm{~h}$ HRT and $2 \mathrm{psi} \mathrm{H}_{2}$ pressure. The performance of methane gas as an electron donor was also investigated in nitrate removal (Modin et al., 2008). However, methaneoxidizing bacteria are still not well-recognized, especially for the anoxic condition. Thus, oxygen is concurrently pressurized with methane to enhance the nitrate reduction kinetics (Modin et al., 2008). Although the MBfR had shown high denitrification rates, disadvantages such as biofilm acclamation in the reactor and microbial growth, attachment, and detachment are considered one of the critical factors that affect the MBfR performance. Thus, several investigations are being conducted to determine the optimum technique for nitrate removal from drinking water.

\section{Ion Exchange Membrane Bioreactor (IEMBR)}

In some parts of the world, ion exchange is a preferable treatment method to remove nitrate for economic reasons. However, nitrate removal via biological treatment is also a competing method, mainly since no waste concentrate had to be stored, which led to other environmental pollution issues. This treatment method combines an ion-selective homogeneous membrane (nonporous) - bioreactor, which has the advantage of limiting the mixing of microbial waste with treated water (Fonseca, et al., 2000). Furthermore, reducing the amount of brine is regarded as an additional benefit of this treatment (Fonseca, 1999). Figure 3 depicts the ion exchange membrane bioreactor configuration used in Velizarov et al.'s (2000) research. The operational conditions of the experiment are as follows: polluted water flows through the ion exchange module at a rate of 0.03 $\mathrm{L} / \mathrm{hr}$ with a hydraulic residence time of $2.67 \mathrm{~h}$. Moreover, the effluent from the membrane module will flow to a mixing container containing the biomedia, including the denitrifying bacteria and the electron donor, ethanol, and the required nutrients for biomass culturing. The biomedia was circulated between the ion exchange membrane and the container at a flow rate of $9 \mathrm{~L} / \mathrm{h}$. Although this type of configuration seems to be complex and the denitrification rate is relatively slow, the advantage of isolating the biomass from the treated water is considered a significant contribution of ion-exchange membrane bioreactor treatment. Table 2 illustrates a comparison between the two ion-exchange bioreactor studies. The membrane fouling and organic loading rate had not been investigated thoroughly yet for optimizing this treatment and overcoming some of the disadvantages, such as scaling form sources with hard water that could hinder the reactor's denitrifying efficiency. Moreover, the drawback of using ion exchange solely without a membrane bioreactor requires a 


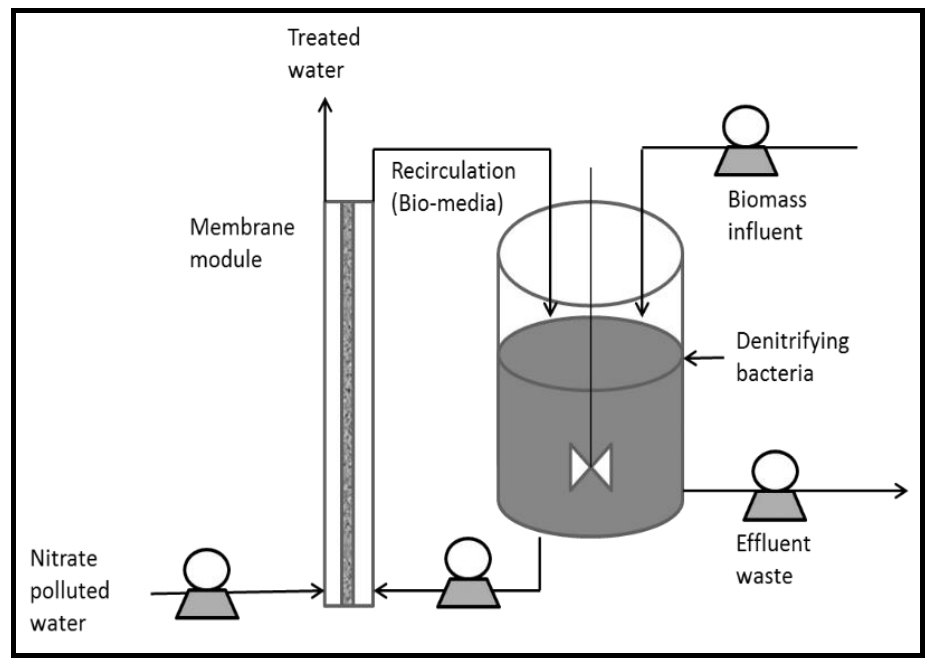

Figure 3: Ion-Exchange MBR Schematic Diagram

Source: Velizarov et al (2000)

Table 2. Ion-exchange bioreactors denitrification rates

\begin{tabular}{ccccc}
\hline Electron donor & $\begin{array}{c}\mathbf{N O}_{\mathbf{3}}-\mathbf{N} \\
\text { Influent }\end{array}$ & $\begin{array}{c}\mathbf{N O}_{\mathbf{3}}-\mathbf{N} \text { Denitrification } \\
\text { rate }\end{array}$ & $\begin{array}{c}\text { Removal } \\
\text { Efficiency }\end{array}$ & References \\
\hline & $\mathbf{( m g / L )}$ & $\mathbf{( g / \mathbf { m } ^ { 2 } \mathbf { d } )}$ & $\mathbf{( \% )}$ & \\
$\mathrm{C}_{2} \mathrm{H}_{6} \mathrm{O}$ & 50 & 7.0 & 99 & Fonseca et al, 2000 \\
$\mathrm{C}_{2} \mathrm{H}_{6} \mathrm{O}$ & $10-25$ & 33 & 85 & Velizarov et al, 2000 \\
\hline
\end{tabular}

periodic regeneration process for the brine and the disposal of highly polluted waste. Furthermore, there is a relative absence of research in bench or pilot scale in this type of configuration.

\section{Biofilm-Electrode Reactor (BER)}

Sakakibara and Kuroda (1993) first investigated and developed this nitrate removal system. This treatment technology, biofilm electrode reactor (BER), utilizes singleor multi-cathode reactor configurations, with autotrophic denitrifying bacteria attached to the cathode surface utilizing granular activated carbon (GAC) for biofilm attachment. In addition, a microfiltration membrane is included in the system for microbial filtration. Moreover, hydrogen gas (electron donor) is produced through water electrolysis (Zhao et al., 2012; Posnansky et al., 2002; McAdam and Judd, 2006). The following stoichiometry presents the overall denitrification reaction:

$$
\mathrm{NO}_{3}^{-}+5 e^{-} \rightarrow 3 \mathrm{H}_{2} \mathrm{O} \rightarrow 1 / 2 \mathrm{~N}_{2}+6 \mathrm{OH}^{-} \quad \text { Eq. } 2
$$

There are several disadvantages of BER systems, such as providing gaseous electron donors to the bioreactor through diffusion through a membrane. Moreover, the issue of low hydrogen solubility requires large volumes of hydrogen molecules to achieve adequate denitrification rates in addition to hydrogen's explosive potential, which can cause a safety issue (Chen et al., 2014). Chen et al. (2014) investigated the BER system for nitrate removal. The observed optimum current was $120 \mathrm{~mA}$ for nitrate degradation rate. However, high nitrite $\left(\mathrm{NO}_{2}\right)$ concentrations were observed in the effluent $(16 \mathrm{mg} / \mathrm{L}$ $\left.\mathrm{NO}_{2}-\mathrm{N}\right)$, only at high nitrate loadings $(500 \mathrm{mg} / \mathrm{L})$, which remains much higher than the regulated nitrite- $\mathrm{N}$ in Canada $(1 \mathrm{mg} / \mathrm{L})$ for drinking water. Furthermore, at a high nitrate loading rate of $300-500 \mathrm{NO}_{3}-\mathrm{N} \mathrm{mg} / \mathrm{L}$, the denitrification rate was hindered. They also reported an optimal denitrification rate at the carbon to nitrogen ratio of 1.0 and at neutral $\mathrm{pH}$ and a temperature of $25-30^{\circ} \mathrm{C}$. In an earlier study by Zhao et al. (2011), the BER system was investigated for nitrate reduction in both autotrophic and heterotrophic denitrification combined. The influent nitrate- $\mathrm{N}$ concentration was $50 \mathrm{mg} / \mathrm{L}$. The reported results were promising: the nitrate removal efficiency was $100 \%$ at a hydraulic retention time of $(8 \mathrm{~h})$; carbon to nitrogen ratio was 1 , and the current was $10 \mathrm{~mA}$. However, the total removal of the carbon source (methanol) was only found at the following optimum conditions: carbon/nitrogen ratio of 0.75 and a current value of $40 \mathrm{~mA}$. Yet, the nitrate removal efficiency dropped slightly to $97 \%$.

Several studies have investigated the considerable impact of $\mathrm{pH}$ on the performances of such small reactors, including but not limited to hydrogen dissolution affected by 
Table 3. BER denitrification rate with various carbon sources

\begin{tabular}{|c|c|c|c|c|c|c|c|}
\hline Carbon Source & Current & $\begin{array}{c}\mathrm{NO}_{3}-\mathrm{N} \text { Influent } \\
\text { Concentration } \\
\mathrm{mg} / \mathrm{L}\end{array}$ & $\mathrm{C} / \mathrm{N}$ & HRT & $\begin{array}{c}\mathrm{NO}_{3}-\mathrm{N} \\
\text { Denitrification } \\
\text { Rate } \\
\left(\mathrm{g} / \mathrm{m}^{2} . \mathrm{d}\right) \\
\end{array}$ & $\begin{array}{c}\text { Removal } \\
\text { Efficiency } \\
\% \\
\%\end{array}$ & References \\
\hline Carbon dioxide & 200 & $20-492$ & - & - & 0.17 & 98 & Park et al. (2005) \\
\hline Methanol & 40 & - & 0.75 & 8 & 50 & 97 & Zhao et al. (2011) \\
\hline Carbon dioxide & 120 & 350 & 1.0 & & 0.22 & - & Chen et al. (2014) \\
\hline Carbon dioxide & 5 & 23 & - & 10 & - & 100 & $\begin{array}{c}\text { Feleke and Sakakibara } \\
(2002)\end{array}$ \\
\hline Sodium acetate & 80 & 35 & 1.0 & 8 & - & 90 & Bao and Наo (2006) \\
\hline Sodium acetate & - & 100 & 3.0 & 10 & - & 93 & Feng et al. (2008) \\
\hline
\end{tabular}
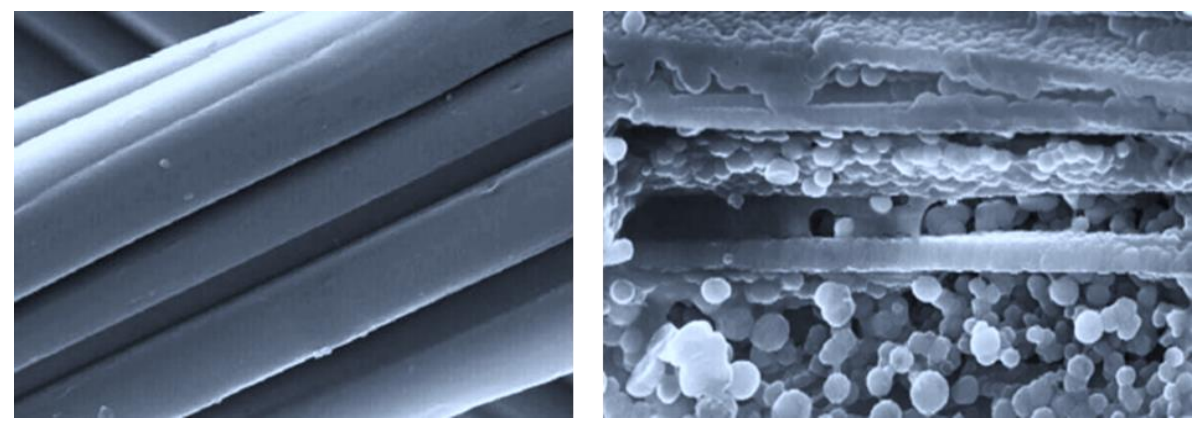

Figure 4: SEM image showing the biomass attachment to the cathode on the right, compared to the cathode surface on the left, prior inoculation

Source: Park et al (2005)

dissolved oxygen concentration and other hydraulic factors (Prosnansky et al., 2002; Zhao et al., 2012; Chen et al., 2014). Prosnansky et al. (2002) incorporated a microfiltration module with a pore size of $0.2 \mu \mathrm{m}$ to the BER system to remove micro-particles leaching from the BER compartment. In fact, this is one of the significant drawbacks of BERs that should be addressed in future studies. Additionally, Park et al. (2005) found that at higher values of applied current $(200 \mathrm{~mA})$, the nitrate removal efficiency was $98 \%$ in the absence of any organic source. Table 3 illustrates some of the differences among different BER studies, recognizing the reported high removal efficiencies. Furthermore, the authors reported a nitrate reduction rate of $0.17 \mathrm{mg}$ nitrate- $\mathrm{N} / \mathrm{cm}^{2}$.d. Regarding the biofilm attachment and growth on the cathode surface; the authors have provided two images, illustrating the denitrifying microbial culture attached to the electrode surface in comparison to the electrode surface before inoculation (Figure 4). It can be argued that the lack of organic carbon traces analysis in the effluent can impact the reliability and validity of such configurations for drinking water.

\section{Conclusions}

This study provides an overview of scientific literature regarding bioreactors to remove nitrate from water drinking. The principles, advantages, and limitations of bioreactors for removing nitrate from drinking water have been discussed in detail in this review paper. Although treatment techniques such as ion-exchange technology, reverse osmosis, and electro-dialysis are considered the most used treatment methods for nitrate removal from drinking water, the emerging biological denitrification via various membrane bioreactor configurations are rivaling techniques proposed for full application in the field, providing denitrification rates up to $4.0-50 \mathrm{~g} / \mathrm{m}^{2}-\mathrm{d}$ and 99\% removal efficiency. Moreover, biological denitrification has been researched thoroughly as an eco-friendly alternative to the harmful chemical processes of nitrate removal, such as the disposal of concentrated waste, which requires further, relatively expensive, post-treatment.

Biological treatment also has its drawbacks, including the need for further treatment to remove any excess organic carbon resulting from heterotrophic denitrification. Microbial contamination as secondary pollution, on the other hand, necessitates additional treatment, such as adsorption with granular activated carbon (GAC).

Overall, this study reviewed various membrane/reactor configurations, both chemical and physical, as well as several biological techniques for removing nitrate from drinking water, discussing their performance and some design aspects, as well as the advantages and disadvantages 
of each configuration.

\section{Conflict of Interests}

The authors declare that there is no conflict of interests regarding the publication of this manuscript.

\section{REFERENCES}

Aydın E, Şahin M, Taşkan E, Hasar H, Erdem M (2016). Chlortetracycline removal by using hydrogen based membrane biofilm reactor. J. hazardous materials, 320:88-95.

Bao LS, Hao W S (2006). Removal of nitrate nitrogen using biofilm-electrode process. Industrial Water \& Wastewater, 37(6), 45.

Buttiglieri G, Malpe F, Daverio E, Melchiori M, Nieman H, Ligthart J (2005). Denitrification of drinking water sources by advanced biological treatment using a membrane bioreactor. Desalination, 178: 211-218.

Chena D, Yanga K, Wanga H (2014). High nitrate removal autohydrogenotrophic bacteria in a biofilm-electrode reactor. Desalination and Water Treatment.

Chung J, Rittmann BE, Wright WF, Bowman RH (2007). Simultaneous bio-reduction of nitrate, perchlorate, selenate, chromate, arsenate, and dibromochloropropane using a hydrogen-based membrane biofilm reactor. Biodegradation, 18(2):199-209.

Dordelmann 0 (2009). Full-scale biological denitrification plants in Germany, Austria and Poland. In: Proceedings of the AWWA Water Quality and Technology Conference, Seattle, WA. American Water Works Association, Denver, Colorado.

Dubrovsky N, Hamilton P (2010). Nutrients in the nation's streams and groundwater: national findings and implications. U.S. Geological Survey, Reston, Virginia (Fact Sheet 2010-3078; pubs.usgs.gov/fs/2010/3078/).

Ergas SJ, Reuss AF (2001). Hydrogenotrophic denitrification of drinking water using a hollow fibre membrane bioreactor. Journal of Water Supply: Res. Technol.-AQUA, 50(3), 161-171.

Fabbricinoa M, Pettab L (2007). Drinking water denitrification in membrane bioreactor/membrane contactor systems. Desalination, 210: 163-174.

Fangang M, Fenglin Y, Shi B, Zhang H (2008). A comprehensive study on membrane fouling in submerged membrane bioreactors operated under different aeration intensities. Separation and Purification Technology, 59:91-100

Feleke ZY, Sakakibara (2002). A bio-electrochemical reactor coupled with adsorber for the removal of nitrate and inhibitory pesticide. Water Research. 36: 3092-3102.

Feng YH, Shen J, Yang JL, Chen X (2008) Technological conditions and process fluidized-bed biofilm reactors. Water Research 38 (17):3719-3728.

Fonseca AD, Crespo JG, Almeida JS, Reis, MA (2000). Drinking water denitrification using a novel ion-exchange membrane bioreactor. Environmental Science \& Technology, 34:1557-1562

Fuchs W, Schatzmayr G, Braun R (1997). Nitrate removal from drinking water using a membrane-fixed biofilm reactor. Applied Microbiology and Biotechnology, 48:267-274.

Guter GA (2021). Nitrate removal from contaminated groundwater by anion exchange. In Ion Exchange Technology (pp. 61-113). CRC Press.

Health Canada. (2013). Guidelines for Canadian Drinking Water Quality: Guideline Technical Document - Nitrate and nitrite. (http://hc-sc.gc.ca/ewh-semt/pubs/watereau/nitrate_nitrite/index-eng.php

Kapoor A, Viraraghavan T (1997). Nitrate removal from drinking water-review. J. Environ. Eng., 123(4): 317380.

Kinyage JPH, Pedersen PB, Pedersen LF (2019). Effects of abrupt salinity increase on nitrification processes in a freshwater moving bed biofilter. Aquacultural Engineering, 84:91-98.

Knowles R (1982). Denitrification. Microbiological Rev., 46(1):43-70.

Lee KC, Rittmann, BE (2002). Applying a novel autohydrogenotrophic hollow-fiber membrane biofilm reactor for denitrification of drinking water. Water research, 36(8):2040-2052.

Mansell BO, Schroeder ED (1999). Biological denitrification in a continuous flow membrane reactor. Water Research, 33(8):1845-1850.

Mao X, Myavagh PH, Lotfikatouli S, Hsiao BS, Walker HW (2020). Membrane bioreactors for nitrogen removal from wastewater: A review. Journal of Environmental Engineering, 146(5), 03120002.

Martin K, Nerenberg R (2012). The membrane biofilm reactor (MBfR) for water and wastewater treatment: Principles, applications, and recent developments. Bioresource Technol, 122: 83-94.

McAdam EJ, Judd SJ (2006). A review of membrane bioreactor potential for nitrate removal from drinking water. Desalination, 196:135-148.

McAdam EJ, Judd SJ (2008). Immersed membrane bioreactors for nitrate removal from drinking water: Cost and feasibility. Desalination, 196:135-148.

Melin T, Jefferson B, Bixio D, Thoeye C, De Wilde W, De Koning J (2006). Membrane bioreactor technology for wastewater treatment and reuse. Desalination, 187:271282.

Meyer KJ, Swaim PD, Bellamy WD, Rittmann BE, Tang Y (2010). Biological and ion exchange nitrate removal evaluation. Water Research Foundation, Denver, Colorado (Report No. 4131).

Missimer TM, Ghaffour N, Dehwah AHA, Rachman R (2013). Subsurface intakes for seawater reverse osmosis facilities: Capacity limitation, water quality improvement, and economics. Desalination 322, p. 37-51.

Modin O, Fukushi K, Nakajima F, YamamotoK (2008). Performance of a membrane biofilm reactor for denitrification with methane. Bioresource technology, 
99(17):8054-8060.

Nuhoglu A, Pekdemir T, Yildiz E, Keskinler B, Akay G (2002). Drinking water denitrification by a membrane bio-reactor. Water Research, 36(5):1155-1166.

Park HI, kun KD, Choi YJ, Pak D (2005). Nitrate reduction using an electrode as direct electron donor in a biofilmelectrode reactor. Process Biochemistry, 40(10):33833388.

Prosnansky M, Sakakibara Y, Kuroda M (2002). High-rate denitrification and SS rejection by biofilm-electrode reactor (BER) combined with microfiltration. Water Research, 36:4801-4810.

Rabah FK, Dahab MF (2004). Nitrate removal characteristics of high performance fluidized-bed biofilm reactors. Water Research, 38(17):3719-3728.

Ravnjak M, Vrtovšek J, Pintar A (2013). Denitrification of drinking water in a two-stage membrane bioreactor by using immobilized biomass. Bioresource Technol., 128, 804-808.

Rezania B, Oleszkiewicz JA, Cicek N (2007). Hydrogendependent denitrification of water in anaerobic submerged membrane bioreactor coupled with a novel hydrogen delivery system. Water Research, 41: 10741080.

Sakakibara Y, Kuroda M (1993). Electric prompting and control of denitrification. Biotechnology and Bioengineering, 42(4):535-537.

Temkin A, Evans S, Manidis T, Campbell C, Naidenko, OV (2019). Exposure-based assessment and economic valuation of adverse birth outcomes and cancer risk due to nitrate in United States drinking water. Environmental Research, 176, 108442.

U.S. EPA (2002). Demonstration project at Fruitland, ID, sixmonth evaluation report. Water Supply and Water Resources Division, National Risk Management Research Laboratory, Office of Research and Development, U.S. Environmental Protection Agency, Cinnicinati, Ohio (EPA/600/R-07/017).

Velizarov S, Rodrigues, CM, Reis MA, Crespo, JG (2000). Mechanism of charged pollutants removal in an ion exchange membrane bioreactor: drinking water denitrification. Biotechnology and bioengineering, 71(4):245-254.

WHO (2011). Guidelines for drinking-water quality. World Health Organization, 216:303-304.

Wintgens T, Rosen J, Melin T, Brepols C, Drensla K, Engelhardt N (2003). Modelling of a membrane bioreactor system for municipal wastewater treatment. J. Membrane science, 216(1-2):55-65.
Xia S, Zhong F, Zhang Y, Li H, Yang X (2010). Bio-reduction of nitrate from groundwater using a hydrogen-based membrane biofilm reactor. J. Environ. Sci., 22(2) :257262.

Zhang L, Fei Y, Ding, H, Sheng M, Liu Y (2011). Preliminary study of groundwater denitrification using a composite membrane bioreactor. Frontiers of Environ. Sci. Engineering, 5 (4):604-609.

Zhao Y, Zhang B, Feng C, Huang F, Zhang P, Zhang Z, Sugiura $N$ (2012). Behavior of autotrophic denitrification and heterotrophic denitrification in an intensified biofilmelectrode reactor for nitrate-contaminated drinking water treatment. Bioresource Technology, 107:159-165. 